\title{
INFLUENCE OF THE RIGHT TO THE ENVIRONMENT ON \\ SUSTAINABLE DEVELOPMENT FROM THE PERSPECTIVE OF INTERNATIONAL LAW

Akramosadat $\mathrm{Kia}^{1}$

\begin{abstract}
Nature is one of the most important pillars of human life, which is why the environment has been considered in all historical periods. At first, contemporary international law seeks to protect the environment as part of international environmental law, but the inadequacy of this protection and the need to protect the environment for Nowadays's human beings and future generations, the link between the

realization of many human rights, civil, political or economic, social and cultural rights. However, the exercise of this right requires a level of development which in turn provides for a greater degree of environmental degradation. Hence, the international community since the nineties has promoted the idea of sustainable development at all levels of national, regional and the international has put it on its agenda.
\end{abstract} environment and human rights It was considered because legal protection of human rights could be a means to protect the environment. Hence, in the context of the third generation of human rights, a new right called "the right to the environment" was created in international human rights instruments, in which the environment was raised as a human right. This right is not only a reminder of the solidarity rights that are categorized in the third generation of human rights, but also necessary for the
Keywords: rights, human rights, environment, healthy environment, sustainable development

\section{Introduction}

Nowadays, the natural environment has been damaged due to the overuse of natural resources and the lack of attention to environmental issues and the lack of respect for the proper development of the concept of sustainable development. In recent

\footnotetext{
${ }^{1}$ Department of international law, Damavand Branch, Islamic Azad University, Tehran, Iran
} 
decades, the development of cities and the increase in human population and climate change and the occurrence of persistent and long-term droughts have caused environmental problems and pollution. The problem of pollution does not have any boundaries or realms. The climate transmits hazardous contaminated material from one region or country to another. What in this regard seriously threatens the human environment is the inaccurate degradation of the environment and its creatures. Therefore, some lawyers try to preserve these rights and improve the status of human rights by introducing environmental rights. They believe that human rights have the right to protect the environment for humanitarian purposes.

\section{Undoubtedly Nowadays,} development in its new meaning is sustainable development alongside human rights, in such a way that environmental protection is considered as an example of international solidarity. The first international document that addresses the relationship between environmental protection, development and human rights seems to be the Stockholm Declaration of 1972. One cannot conceal the relationship and the interaction between environmental issues and human rights. The right to a healthy environment is one that both political and civil rights defenders and conservationists emphasize and protect. The international system is not like any other system, and it is constantly changing, and international law, which relates to the international community, has undergone dramatic changes, because international law is essentially a law-based treaty. As stated in the sources, the relationship between the right to the environment, international law and international environmental law can be investigated, because the development of the concept of international law and the development of its field of action are the result of the emergence of concepts such as human rights Which has led to the development of international rules based on the direct and immediate interests of States to the rules governing the interests of the international community and the common interests of humanity, so the concern for protecting human rights has led to the extension of these categories of rules.

The ultimate goal of the rules of international environmental law is not the direct and uninterrupted interests of the state, but the benefits of humanity 
and the improvement of the human destinies. For this reason, the final statement of the Stockholm Conference in 1972, proclaiming the right to a healthy environment, constitutes a fundamental link between protection Created the environment and human rights, and marked the beginning of a new era of international law.

The present study will examine broadly the fundamental principles of international environmental law, which are the right to a healthy environment. The special observation of this study is that this research is not only viewed from the perspective of international environmental law but also from the perspective of international law on sustainable development. Environmental and environmental debate Although it is in itself a branch of domestic law, it has become a transnational, transnational, and international issue due to the advent of industry and technology that has caused environmental problems and pollution. Nowadays, the environment and environment protection are a relatively new area for international regulation, and highlights the importance of addressing the issue.

On the other hand, international law has set rules and regulations for responding to global environmental problems and problems, which has led to the emergence of a branch in international law called International Environmental Law, one of the newest branches International law.

The overall objective of this study is to provide a concrete framework for the role and importance of international environmental protection laws and identifying key factors in international environmental law through the development of the right to the environment.

\section{The main hypothesis}

Regarding the vital importance of the right to a healthy environment, the two-way impact of the right to the environment and sustainable development from the perspective of international environmental law, in the framework of the framework of environmental diplomacy and international engagement in the light of institutional arrangements Human rights will be realized.

\section{Research method}

This research is a composite (descriptive-analytic) method. The method of collecting more is based on 
the library method and the use of articles and dissertations in the National Library, Parliament, Tehran University and Tarbiat Modares, as well as the use of credible sites such as Normags, Iran Doc, Mag Iran and sites of research institutes and other poles and other Scientific resources in country.

Regarding the right to a healthy environment, scholars have addressed it, including: Dr. Ali Mashhadi in the book The Right to a Healthy Environment of Iran and France, published in 2013 by the Legal Publishers, in the context of public law and human rights, to examine the issue. Paid.

Dr. Sobhan Tayebi, in the book "Environmental Diplomacy and International Law on Sustainable Development", a collection of opinions and opinions published in Majd Law Magazine in 2016, discusses the symbiotic nature of international environmental law and international law as a sustainable development, and advances environmental diplomacy. To realize the right to a healthy environment.

Dr. Mehdi Firoozi, in the book on environmental rights, published by the Jahad University Press in 2007, investigated the fundamental environmental right framework.

Dr. Mohammad Hosein Ramezani Ghavam Abadi and Hassan Shafiq Fard in the Journal of World Politics Volume 5, Issue 1, Autumn 2016, on Sustainable Development and the Right to a Healthy Environment.

Right now, the right to the environment is the most developed issue that has been discussed and analyzed as solidarity rights.

In international texts and documents, the definition of the right to the environment is provided, but Articles 14 and 15 of the draft third international law of solidarity rights in expressing the right to the environment of every human being and all human beings are grouped in the right to a healthy and balanced environment. Environmentally friendly and favorable for economic, social, cultural and legal development.

States Parties commit that natural conditions of life do not suffer from adverse changes that harm human health and collective well-being, the harm that is necessary for the development of society and is not a way to avoid it is considered acceptable, on the other hand The first principle of the Stockholm Declaration states: "Human 
beings have the fundamental rights to have freedom, equality and proper living conditions in an environment that allows him to live with dignity and prosperity. $\mathrm{He}$ is officially responsible for protecting and improving the environment for present and future generations.

The environment includes all the conditions for an encounter with a life of continuous life, with peace and health for present and future generations. Citizens can once again achieve their rights to create a natural environment, artificial environment or human being, and their social environment is protected by laws and regulations. In a city like Tehran and ... the social environment is far more influential than the impact of technology and industry in the environment, since most issues, such as pollution of water, air and waste, are due to some social factors such as population increase, false culture Urbanization and rising consumption. This point is also mentioned in Article IV, paragraph (a), of the United Nations Conference on the Status of the United Nations, and is due to a lack of development. The goal of environmental law is to limit the impact of human activities on elements or natural environments, and this goal is effective not only in the direct and immediate interests of the state, but also in the interests of citizens and the improvement of their fate. In addition, environmental rights are one of the fundamental and fundamental rights of citizenship, because it is a healthy environment that can guarantee physical, mental and right of life.

Therefore, these rights can also be considered as a function of civil rights, since they do not give these rights to man, but his natural right. Environmental law is such that in addition to the right to claim the right of the right, the other right is also affected by the exercise of the right. If the environmental rights of the ethics circle enter the circle of rights and laws (the law of the subject), the guarantee will be implemented, so, for example, when the creation of a video pollution crime and the punishment for it, you can complain to the law enforcement authorities $\mathrm{He}$ demanded the right to be damaged.

\section{The concept of sustainable development}

Sustainable development, based on the definition of the United Nations Commission on the Environment and Development, known as the Brentland Commission, and the United Nations 


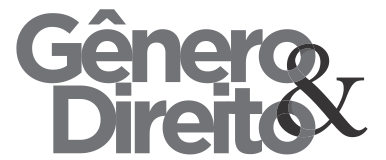

Periódico do Núcleo de Estudos e Pesquisas sobre Gênero e Direito

Centro de Ciências Jurídicas - Universidade Federal da Paraíba

V. 8 - No 03 - Ano 2019

ISSN | 2179-7137 | http://periodicos.ufpb.br/ojs2/index.php/ged/index
Commission on Environment and

Development in 1987 mean that development will meet the needs of the present without compromising the ability of future generations to meet their needs. doing. In other words, sustainable development is a comprehensive approach that aims to promote development in ways that do not endanger the environment or dispose of natural resources in a way that is available in the future. The report adds that the conditions are not only applicable to environmental policies, but also to economic and social policies.

The most complete definition of sustainable development consists of two key concepts: first, the concept of the need for the basic needs of the poor world, which must be given priority. Second, the idea of the constraints imposed by the state of technology and social organization on the ability of the ecosystem to meet the present and future needs. While the provision of the needs of the poor is not necessarily consistent with the needs of future generations, it is clear that the countries of the world do not have the same level of energy, clean water, clean air, political freedom and the protection of their societies from war crimes and warfare. In this regard, sustainable development of the environment involves water and waste, society (employment, human rights, gender equality, peace and human security) and economics (poverty reduction, corporate responsibility, and accountability).

Sustainable development means the management and conservation of basic resources and the introduction and application of technological advancements and organizational structures that ensure continuous and satisfying human needs for the present and future generations. Sustainable development that protects land, water resources and plant and animal genetic resources is not only harmful to the environment, but also technically fit, economically valuable and socially acceptable. This is the definition that the grocery organization And agriculture has provided sustainability development. According to Makhdoum, the maximum and stable returns are the true concept of sustainable development. Sustainable development as a concept, based on the equality of generations, means that generations must not eliminate the ability of future generations to use resources. 
What is certain is that sustainable development should not only be considered as a set of methods, but also considered as a kind of insight in which different aspects of economic, social and even philosophical lies, and its cultural dimensions are less than aspects Technical and technical not relevant. If we consider only the economic and environmental aspects of sustainability, sustainable development will become an anti-development tool.

Sustainable development has also been made up of two areas of development and sustainability. It is about development, process and goals. The process of growth and change reflects the goals of the initial needs. Sustainability must exist in three social, environmental and physical contexts. As a result of sustainable development, that is, the sustainability of objects, the preservation of the natural environment and social equilibrium through the processes of growth and change, and the satisfaction of reasonable human needs.

Right to the environment and human rights

Although there is no serious and effective legal research on the nature of the right to the environment; however, the transformation of this right into the contemporary human rights system reflects the existence of a completely separate nature for the right to make the first analysis of this right with Challenges. Understanding the nature of the right to the environment depends on determining the status of this right in the human rights collection. In fact, what is the right of this right to submit a picture of it among other human rights?

Various ideas have been presented in the legal literature on the right to the environment. However, they can be divided into two general categories. A bunch of analyzes have denied the existence of such a right. Basically, with each new wording, new rights in the human rights package are opposed to the ambiguity of their nature and their lack of recognition and consolidation in the human rights system, and emphasize that there is no need for any claim In the form of "right".

\section{Conclusion}

Addressing the harmful effects on the environment in the current world requires the use of new tools. Human and environmental integrity in the light of international environmental law The traditional environment brings environmental law to the protection of 
the environment of countries. The specification of the fundamental and fundamental human rights in the attitude to the environment and the necessity of protecting them, regional and global human rights arrangements and systems, ensures the exercise of this right.

One of the concerns of environmentalists in the international protection and protection of the environment is the lack of a structured legal structure that could bring environmental damages to the benefit of the victims. The international environmental legislation is a new issue that began at the 1992 Rio Conference, but the Stockholm Conference of 1972 provided the subject of legislation in this field in domestic law. And on the brink of other acts of custom and custom. Attorneys and judges, and scholars and lawyers deal with the laws of the environment.

On the other hand, international environmental law has not succeeded in identifying individuals as individuals of international law, thus abandoning those who are the main victims of environmental abuses at an internationally defenseless level.

In the field of international human rights, its growing trend, especially in the past decade, has evolved through the establishment of local, national, international institutions. As many international systems in the Americas, Europe, Africa and Islamic countries are now focusing on human rights, some of them, such as the system of American and European countries, have established a positive step towards the defense of human rights through institutionalization and institutional arrangements, and in The efforts to support and improve respect for human rights in the national and international arena have been somewhat successful. Human rights legislation has entered into national arena through treaties, declarations, resolutions and procedures of international law. One of the most important achievements of the international human rights system is the direct access of victims to international human rights institutions. In this field, individuals The titles of the lawyers can, from the point of view of the law, be able to sue and lodge complaints about the misuse of human rights by governments.

But the defense of human rights in the environment is still the starting point. Claiming individuals against the state sometimes relates to environmental problems. The international human 
rights system is a unique place for individuals to file lawsuits to defend their rights, including violations of their right to their own environment.

By extending the concept of protecting human rights, the right to a healthy environment can be interpreted through it. Nowadays, more than ever, the society is aware of the relationship between human life and the environment, and the pollution and destruction of the environment can put human life at serious risk. Human dependence on environmental quality is evident. Therefore, the environment is considered as a human rights dimension.

The internationally recognized right has not yet been universally recognized as an integral part of the basic rights of the first and second generations of humankind, and despite the fact that the human right to benefit from the healthy environment in human rights instruments of the three geographic regions of America, Europe and Africa But international human rights have not yet become widespread and universal in nature, so its effects will be limited to just governments.

Regarding the contrast between the concept of environmental law and sustainable development, the issue of
466

sustainable and comprehensive development, both in the developed world and in the developing world, is of interest and concern Nowadays. Development in the real sense of the word, with the semantic burden of progress or excellence, must be comprehensive, inclusive, and sustainable, in order to create a coherent movement of forces within society. When it comes to the full development of development, society is considered a system, all of its components requiring a change in quantitative and qualitative increase. Once this change can be useful in the path to sustainability. In other words, universal development without sustainable development loses its human meaning. Sustainable development of conservation of resources and the environment and the contribution of the future is posed. Development should not be at the expense of future generations. In a comprehensive and sustainable development, the whole of society's facilities must be preserved as a set, in the presence of all, for future generations. Resources and facilities should not be diminishing, but rather renewed and growing.

In general, actions can and should be taken to achieve sustainable 
development in the sense of reconciling development and protection of the environment in the context of human rights, respect for all human rights and Amiri Ghaem Maghami, Abdolmajid, Law of Obligations, Volume 1, Volume, 1999

freedoms.

\section{Research suggestions}

1. Research on existing regulations related to environmental rights in different countries and compare them with each other.

2- Research on the formation of internal and, especially, international regulations in the field of environmental protection

\section{Research constraints}

1. Time limit: time limit for access to resources and work progress.

2. Financial constraints: Financial constraints for access to resources and work.

3. Restriction of skills: the lack of correct and complete access to written sources such as books, articles and ...

\section{References}

Arfaei, Aaliyeh et al, Human Rights in the View of International Assemblies, Tehran Political and International Studies, 1993

Ansari, Mohsen, Status and role of the environment in the development programs of the Islamic Republic of Iran and its comparison with the prerevolutionary plans, 2000

Eivlolan, Third World and Environment, Translation by Ferozoosgari, Manouchehr, Tehran, Chapakhsh Publication, 1994 5- Aghaei, Bahman, International Law of the Sea and the Issues of Iran, Tehran, Library of the Ganj Danesh, 1995

Eftekhari Zadeh, Seyyed Fardaad, A Model for Ordinary Citizenship Training in the Third Century. Ph.D., Research Sciences, Humanities, 2003.

Fahimi, Aziz Allah, Civil liability due to environmental degradation; Comparative study on the rights of Iran, France, international documents and documents; Ph.D. in Private Law; Imam Sadiq University (2008). 
Periódico do Núcleo de Estudos e Pesquisas sobre Gênero e Direito

Centro de Ciências Jurídicas - Universidade Federal da Paraíba

V. 8 - $\mathrm{N}^{\circ} 03$ - Ano 2019

ISSN | 2179-7137 | http://periodicos.ufpb.br/ojs2/index.php/ged/index

468

Golparian, Roghaieh, Participation,

BSc, Faculty of Social Sciences,

University of Tehran, 1975 